\title{
Deteç̧ão e identificação molecular de vírus associados a videiras sintomáticas e assintomáticas
}

\author{
Molecular detection and identification of virus associated with symptomatic \\ and symptomless grapevines
}

\author{
Marcos Fernando Basso ${ }^{\mathrm{I}}$ Thor Vinícius Martins Fajardo ${ }^{\mathrm{II}}$ Marcelo Eiras $^{\mathrm{III}}$ \\ Ricardo Antônio Ayub ${ }^{\text {I }}$ Osmar Nickel ${ }^{\text {II }}$
}

\section{RESUMO}

\begin{abstract}
A propagação vegetativa da videira favorece infecções virais múltiplas, com expressão diferencial de sintomas em função da combinação da cultivar ou espécie da hospedeira com a espécie viral. Os objetivos deste trabalho foram detectar e identificar as espécies virais presentes em duas espécies/cultivares de videira: uma sintomática e outra assintomática. DsRNA de ambas as amostras foi submetido à $R T$-PCR com 17 pares de oligonucleotideos especificos para a detecção de Grapevine virus A (GVA), Grapevine virus B (GVB), Grapevine virus D (GVD), Grapevine fleck virus (GFkV), Grapevine fanleaf virus (GFLV), Arabis mosaic virus (ArMV), Grapevine chrome mosaic virus (GCMV), Rupestris stem pitting-associated virus (RSPaV), Grapevine leafroll-associated virus 1 a 4 (GLRaV-1 a -4), além de três pares de oligonucleotideos degenerados. Pelo menos um fragmento amplificado, por par de oligonucleotideos, foi clonado e sequenciado. Plantas sintomáticas e assintomáticas mostraram infecções múltiplas por RSPaV, GLRaV-2 elou GLRaV-3. As sequências de nucleotideos obtidas para sete isolados de RSPaV, três de GLRaV-2 e dois de GLRaV-3 apresentaram identidades superiores a $90 \%$ com espécies homólogas e permitiram a definição das possiveis estirpes presentes nas amostras infectadas. Esses resultados evidenciam a necessidade da diagnose viral baseada em testes especificos para determinar a condição sanitária da videira.
\end{abstract}

Palavras-chave: RSPaV, GLRaV-2, GLRaV-3, Vitis, diagnose, variabilidade.

\section{ABSTRACT}

The vegetative propagation of grapevine facilitates multiple viral infections, with different symptoms which vary according to combinations of cultivar or host species with viral species. The aims of this research were to detect and identify the viral species infecting two grapevine species/cultivars: one symptomatic and one symptomless. DsRNA from both samples was assayed by RT-PCR using 17 pairs of specific primers for detection of the Grapevine virus A (GVA), Grapevine virus B $(G V B)$, Grapevine virus D (GVD), Grapevine fleck virus (GFkV), Grapevine fanleaf virus (GFLV), Arabis mosaic virus (ArMV), Grapevine chrome mosaic virus (GCMV), Rupestris stem pitting-associated virus (RSPaV) and Grapevine leafrollassociated virus 1-4 (GLRaV-1 to -4), besides three degenerate primer pairs. For each primer pair at least one amplicon was cloned and sequenced. Symtomatic and symptomless plants were multiple infected by RSPaV, GLRaV-2 and/or GLRaV-3. The nucleotide sequences of seven isolates of RSPaV, three of GLRaV-2 and two of GLRaV-3 showed identities higher than 90\% with the homologous viral species and allowed to identify possible viral strains in infected samples. These results highlight the necessity of viral diagnosis based on specific assays to determine grapevine sanitary status.

Key words: RSPaV, GLRaV-2, GLRaV-3, Vitis, diagnosis, variability.

\section{INTRODUÇÃO}

A videira pertence à família Vitaceae e ao gênero Vitis, o qual possui várias espécies, destacandose Vitis vinifera L., produtora de uvas finas, de origem européia e conhecida por "uva vinífera" e Vitis labrusca L., produtora de uvas comuns, de origem americana e

'Departamento de Fitotecnia e Fitossanidade, Universidade Estadual de Ponta Grossa (UEPG), Ponta Grossa, PR, Brasil.

"Embrapa Uva e Vinho, CP 130, 95700-000, Bento Gonçalves, RS, Brasil. E-mail: thor@cnpuv.embrapa.br. "Autor para correspondência.

IIIInstituto Biológico, Centro de Pesquisa e Desenvolvimento de Sanidade Vegetal (CPDSV), São Paulo, SP, Brasil. 
conhecida por "uva americana ou comum", esta última predomina no Brasil. Considerando essas duas espécies, destacam-se, em diferentes segmentos desta cadeia produtiva, no Brasil, as cultivares 'Cabernet Sauvignon' ( $\boldsymbol{V}$. vinifera), destinada à elaboração de vinho fino e a cv. 'Isabel' (V. labrusca) para a elaboração de vinho comum, suco ou consumo in natura (GIOVANNINI, 2008).

No Brasil, as viroses ocorrem em todas as regiões vitícolas e a incidência, em várias dessas regiões, em cultivares americanas e viníferas, é bastante expressiva. Dentre os prejuízos causados, citam-se reduções no rendimento e na qualidade das uvas, redução da vida útil do vinhedo e, dependendo da severidade da infecção, pode comprometer totalmente a produção ou até causar a morte da planta (FAJARDO et al., 2003; LIMA, 2009).

Já foram relatadas no mundo pelo menos 60 espécies virais na cultura da videira, embora nem todas se destaquem em importância (MARTELLI, 2009; MONIS et al., 2010). No Brasil, dez vírus foram detectados: Grapevine leafroll-associated virus (GLRaV-1, -2, -3, -5 e -6), Grapevine virus A e B (GVAe $\mathrm{GVB})$, Rupestris stem pitting-associated virus (RSPaV), Grapevine fleck virus (GFkV) e Grapevine fanleaf virus (GFLV). As viroses que se destacam pela incidência e importância econômica são o enrolamento da folha (GLRaV-1,-2 e -3) e o lenho rugoso da videira, complexo formado pelo intumescimento dos ramos (GVB), a acanaladura do lenho de Kober (GVA) e as caneluras do tronco de Rupestris (RSPaV) (FAJARDO et al., 2003; LIMA, 2009).

A videira, por ser propagada vegetativamente, facilita a disseminação e favorece a ocorrência de doenças complexas, pelo acúmulo de diferentes espécies/estirpes virais em uma mesma planta (MARTELLI, 2009). Entretanto, as viroses podem passar despercebidas, por não produzirem sintomas visualmente perceptíveis ou facilmente distinguíveis, o que decorre da expressão diferencial de sintomas na videira. Estes podem variar em função das condições ambientais, do estádio fenológico da planta, da fertilidade do solo e, principalmente, em função da combinação envolvendo a cultivar e/ou espécie da hospedeira e a estirpe e/ou espécie viral. Considerando os sintomas das duas principais viroses da videira (enrolamento das folhas e lenho rugoso), verifica-se uma escala gradativa de expressão de sintomas, partindo das cvs. americanas e híbridas (as quais não exibem sintomas de determinadas viroses ou estes não são característicos ou facilmente perceptíveis) até as cvs. viníferas (nas quais normalmente a expressão de sintomas é evidente). Isso é atribuído à distinta sensibilidade das espécies/cultivares da hospedeira em resposta à infecção viral, ou seja, determinados genótipos são tolerantes à infecção viral (KOVACS et al., 2001; FAJARDO et al., 2003).

Os objetivos deste trabalho foram detectar e identificar molecularmente as espécies virais associadas a duas espécies/cultivares de videiras, uma sintomática e outra assintomática, correlacionando à constatação de infecção viral com a sintomatologia e o tipo de hospedeira.

\section{MATERIAL E MÉTODOS}

As amostras avaliadas foram provenientes de dois vinhedos experimentais da Embrapa Uva e Vinho, Bento Gonçalves (RS): um da cv. 'Cabernet Sauvignon' (videira vinífera, Vitis vinifera), enxertada no porta-enxerto 'Paulsen 1103', em 1995, e outro da cultivar 'Isabel' (videira americana, V. labrusca), pé franco, plantada em 1971. Foram selecionadas duas plantas da cv. 'C. Sauvignon' e três da cv. 'Isabel'. Como controle negativo, selecionou-se a cv. de portaenxerto 'Paulsen 1103', obtida por termoterapia e cultura de tecidos, e comprovadamente sadia.

Os sintomas observados a campo na cv. ' $\mathrm{C}$. Sauvignon', somente a partir do meio do ciclo vegetativo, foram folhas coriáceas com avermelhamento e enrolamento dos bordos das folhas para baixo, com as nervuras principais permanecendo verdes, presença de caneluras no porta-enxerto e no tronco da copa e intumescimento com formação de tecido corticento na base do ramo do ano. Já na cv. 'Isabel', não foram verificados sintomas perceptíveis de infecção viral nas folhas, ramos e tronco, ao longo de todo o ciclo vegetativo.

O dsRNA foi extraído a partir 30 gramas de tecido vegetal obtido de ramos maduros de videira e adotando-se metodologia descrita por VALVERDE et al. (1990). Ao final, o dsRNA foi purificado em coluna de celulose (CF11, Whatman) e ressuspendido em água autoclavada.

A síntese de cDNA e as reações de PCR foram conduzidas conforme metodologia descrita por FAJARDO et al. (2000). As reações foram submetidas a uma desnaturação inicial $\left(94^{\circ} \mathrm{C}\right.$ por $\left.5 \mathrm{~min}\right)$ seguida por 35 ciclos de amplificação: desnaturação $\left(94^{\circ} \mathrm{C}\right.$ por $50 \mathrm{seg})$, pareamento $\left(50^{\circ} \mathrm{C}\right.$ por $\left.50 \mathrm{seg}\right)$ e extensão $\left(72^{\circ} \mathrm{C}\right.$ por $1 \mathrm{~min})$, além da extensão final $\left(72^{\circ} \mathrm{C}\right.$ por $\left.7 \mathrm{~min}\right)$. Para os fragmentos esperados, menores que $500 \mathrm{pb}$, o tempo de extensão foi de $50 \mathrm{seg}$ e, para os pares de oligonucleotídeos degenerados, a temperatura de pareamento foi de $48^{\circ} \mathrm{C}$.

As plantas foram avaliadas quanto à presença de 12 espécies virais: Grapevine virus $A$ 
(GVA), Grapevine virus B (GVB), Grapevine virus D (GVD), Grapevine fleck virus (GFkV), Grapevine fanleaf virus (GFLV), Arabis mosaic virus (ArMV), Rupestris stem pitting-associated virus (RSPaV), Grapevine leafroll-associated virus (GLRaV-1, -2, -3, 4) e Grapevine chrome mosaic virus (GCMV), com 17 pares de oligonucleotídeos específicos, além de três pares de oligonucleotídeos degenerados para a detecção de vírus da família Betaflexiviridae e dos gêneros Closterovirus e Trichovirus/Vitivirus, os quais permitem amplificar fragmentos em diferentes regiões do genoma viral (Tabela 1).

Os produtos da RT-PCR foram analisados em géis de agarose $1,2 \%$, preparados em tampão TBE $\mathrm{pH} 8,0$, tingidos com brometo de etídeo e visualizados em transluminador sobre luz UV. As bandas observadas, correspondentes a fragmentos de tamanhos esperados, foram recortadas dos géis e eluídas com a utilização do kit "HiYield"M Gel/PCR DNA Extraction" (RBC Real Genomics). Os fragmentos de DNA eluídos foram ligados ao vetor pGEM-T Easy (Promega). A seguir, as ligações foram utilizadas na transformação de células competentes de Escherichia coli DH5a, por eletroporação no aparelho Gene Pulse II (Biorad).

O DNA plasmidial das colônias bacterianas transformadas foi extraído utilizando-se o kit Illustra plasmid Prep Mini Spin (GE Healthcare), seguindo as orientações do fabricante. A confirmação da presença dos fragmentos virais clonados nos plasmídeos recombinantes foi realizada por digestão com a enzima de restrição EcoRI (SAMBROOK \& RUSSEL, 2001). Procedeu-se ao sequenciamento automático de nucleotídeos de pelo menos um clone (isolado viral) obtido para cada fragmento amplificado.

As comparações entre as sequências de nucleotídeos (nt) e de aminoácidos deduzidos (aad), obtidas com outros isolados disponíveis em banco de dados (GenBank), foram realizadas utilizando-se o programa BLASTn ou BLASTp do NCBI (www.ncbi.nlm.nih.gov). Foram incluídas nas análises sequências de genes homólogos de isolados "estrangeiros", depositadas no GenBank de isoladostipo de cada espécie viral amplificada, além das estirpes (variantes biológicas caracterizadas com base na sequência de nucleotídeos de seu genoma) definidas e reconhecidas de cada vírus. Para o GLRaV-2, as estirpes consideradas foram: 93/955, PN (=Sem, 94/970), H4, RG, Alfie e BD (ABOU GHANEM-SABANADZOVIC et al., 2000; BERTAZZON \& ANGELINI, 2004; MENG et al., 2005a). Em relação ao RSPaV, foram consideradas as estirpes GRSPaV-VS, GRSPaV-BS, GRSPaV-SG1 e GRSPaV-1 (MENG et al., 2006; ALABI et al., 2010) e Syrah (SY) (LIMA et al., 2006) e Pinot Noir (PN) (LIMA et al., 2009), recentemente identificadas. Para o GLRaV-
3 foi considerada apenas a estirpe "típica" NY (New York) (LING et al., 1997).

\section{RESULTADOS E DISCUSSÃO}

Os resultados obtidos demonstraram a ocorrência de infecções virais múltiplas em todas as cinco plantas avaliadas com RSPaV e GLRaV-2, presentes na cv. 'C. Sauvignon' e RSPaV, GLRaV-2 e GLRaV-3, na cv. 'Isabel' (Tabela 2). Essas plantas não apresentaram infecções com as espécies virais GVA, GVB, GFkV, GFLV e GLRaV-1, já relatadas no Brasil, tampouco com GVD, ArMV, GLRaV-4, GCMV e RSPaV (estirpe $\mathrm{PN}$ ), ainda não relatadas no país.

Como mencionado anteriormente, as plantas avaliadas das cvs. 'C. Sauvignon' e 'Isabel' eram sintomáticas e assintomáticas, respectivamente. Este resultado evidencia a importância de se conhecer o estado fitossanitário da planta, independemente da manifestação ou não de sintomas. Isso adquire ainda maior relevância quando se sabe que mesmo materiais assintomáticos sofrem efeitos negativos decorrentes de infecção viral. KOVACS et al. (2001) determinaram os efeitos da infecção por GLRaV-3 e GFkV em videiras híbridas americanas assintomáticas. Eles observaram decréscimos no peso médio da baga (5-7\%) e no teor de sólidos solúveis totais (2-6\%), além de aumento da acidez titulável do mosto (5-14\%). Os resultados desse trabalho também demonstraram a prevalência nas amostras de três importantes espécies virais que infectam a videira, o que está em concordância com outros relatos em diferentes países vitícolas do mundo (MARTELLI, 2009).

Considerando que todas as cinco amostras apresentaram-se infectadas por RSPaV, conforme determinado pela utilização dos oligonucleotídeos RSPaV_v1/RSPaV-c1, a eficiência de detecção desse vírus com os oligonucleotídeos RSP2/RSP21 (nas amostras CS1, IS2 e IS3) e com os oligonucleotídeos dPR1_v/dPR2_c (nas amostras CS1 e IS3) não foi adequada (Tabela 2). Além das mencionadas anteriormente, não foram observadas quaisquer outras inconsistências nos resultados obtidos com os oligonucleotídeos testados (Tabela 2). Resultados semelhantes foram relatados por BERTAZZON \& ANGELINI (2004), em testes de detecção de diferentes isolados de GLRaV-2, nos quais obtiveram resultados falso-negativos em função do oligonucleotídeo utilizado. MENG et al. (1999) destacam a importância da escolha dos oligonucleotídeos na indexação de plantas infectadas por RSPaV e demonstram que a eficiência entre diferentes pares de oligonucleotídeos testados foi de 85 a 100\%. Por fim, BEUVE et al. (2007) também ressaltam a importância de oligonucleotídeos 
Tabela 1 - Oligonucleotídeos específicos e degenerados utilizados na detecção viral por RT-PCR em videiras.

\begin{tabular}{|c|c|c|}
\hline Vírus & Oligonucleotídeo & Sequência $\left(5^{\prime}-3^{\prime}\right){ }^{\left({ }^{*}\right)}$ \\
\hline \multirow{2}{*}{ GVA } & 766 & GGGGAGGTAGATATAGTAGG \\
\hline & $\mathrm{C} 1197$ & TACCCGTGAGAAATGATGGG \\
\hline \multirow{2}{*}{ GVB } & GVB_v & CAAGCAATTCCCCGAGAGT \\
\hline & GVB_c & TTTAGCCGCACTCCTTGACT \\
\hline \multirow{2}{*}{ GVD } & GVD_v & GACGCAGGGATGTACCTTAGGACG \\
\hline & GVD_c & CCTCTACTTATGGAAATTGCGCTC \\
\hline \multirow{4}{*}{ GFkV } & GFkV_v & ATGAGCCTCCCCGCTGACCTCC \\
\hline & GFkV_r & TCATGACGAGGGAGTGGGGCGG \\
\hline & GFkV_v & AGTACCTCCTCCACCGCACC \\
\hline & GFkV_c & TTTCTCGGGCAGAGAGCCGT \\
\hline \multirow{2}{*}{ GFLV } & GFLVs2515 & GGAAGAGGCCACTTCTTTCCTTGGG \\
\hline & GFLVa3300 & CCCACCAGCTTCGTGATGGTAACGC \\
\hline \multirow{2}{*}{ ArMV } & $\mathrm{H} 428 \mathrm{v}$ & GCGGCGGATTGGGAGTT \\
\hline & $\mathrm{C} 867 \mathrm{c}$ & CGATGGTAGGGGGAGCGTATT \\
\hline \multirow{4}{*}{$\mathrm{RSPaV}$} & RSPaV_v1 & ATGGCAAGTCAAATTGGGAAAC \\
\hline & RSPaV_c1 & TCATTCATGTGTAACATTTGAA \\
\hline & RSP2 & CAAGCATGCTCTTGGCAAC \\
\hline & RSP21 & CCCTCTGGCGATTGAATTG \\
\hline \multirow{2}{*}{ RSPaV-PN } & $2 \mathrm{R}$ & TTCCCCAAACTTCCAACTTAC \\
\hline & PN1F & GATGGATACAAGTTACGGGC \\
\hline \multirow{2}{*}{ RSPaV-SY } & SY9F & AGGATTCCAAACTGTAGAGCAA \\
\hline & SY8R & TTGGTCGTCATCTTCCAGTT \\
\hline \multirow{4}{*}{ GLRaV-1 } & GLRaV-1_v & ATGGCTAGCGTTATATCTCAAA \\
\hline & GLRaV-1_r & TTACACCTTAAGCTCGCTAGTA \\
\hline & LRA & ACGTTGAGATTAGTCTGACTC \\
\hline & CPdR & TCACAGCATCAATATCTTTTCC \\
\hline \multirow{2}{*}{ GLRaV-2 } & $\mathrm{V} 2 \mathrm{CPf}$ & CTAGTCTAAATGGTGTCGA \\
\hline & $\mathrm{V} 2 \mathrm{CPr} 2$ & TTCAGAGAGCTTCGGGCAAG \\
\hline \multirow{2}{*}{ GLRaV-3 } & LR3 $8504 v$ & ATGGCATTTGAACTGAAATT \\
\hline & LR3 9445c & CTACTTCTTTTGCAATAGTT \\
\hline \multirow{2}{*}{ GLRaV-4 } & LR4f & ACCCTTCATAAGCAGGAACC \\
\hline & LR4r & CTTGTGAAACCGACGGCC \\
\hline \multirow{2}{*}{ GCMV } & GCMVs & ATGTGTGCCACTACTGGCATGCA \\
\hline & GCMVa & TTCTCTTCAAGAAATGCCTAAGA \\
\hline \multirow{2}{*}{ Closterovirus } & HSP-P1 & GGITTIGAITTYGGIACIAC \\
\hline & HSP-P2 & RTCIAAIGTICCICCICCCRAA \\
\hline \multirow{2}{*}{ Tricho/Vitivirus } & dPR1_v & GCDAARGCNGGNCARACHHTVGCBTGYTT \\
\hline & $\mathrm{dPR} 2{ }_{-} \mathrm{c}$ & RAAYTCNCCNSWRAANCKCAT \\
\hline \multirow{2}{*}{ Betaflexiviridae } & dRW up1 & WGCIAARGCIGGICARAC \\
\hline & dRW do2 & RMYTCICCISWRAAICKCAT \\
\hline
\end{tabular}

Orientação dos oligonucleotídeos: senso (primeiro linha) e antisenso (segunda linha).

${ }^{(*)}$ As referências originais dos oligonucleotídeos encontram-se em BASSO (2010).

desenhados com base em regiões conservadas, levando-se em consideração a variabilidade entre os isolados da mesma espécie.

Merece destaque a amplificação positiva, a partir de todas as amostras, com os oligonucleotídeos SY9F/SY8R, indicando infecção por RSPaV, estirpe Syrah (RSPaV-SY) (Tabela 2), uma estirpe específica do RSPaV capaz de causar engrossamento na região da enxertia, além de necroses nesta região e ainda não identificada em vinhedos nacionais. Estudos adicionais de caracterização biológica necessitariam ser conduzidos neste caso. Os oligonucleotídeos específicos para a estirpe Syrah foram desenhados com base no gene da replicase, numa região que apresenta significativa variabilidade, permitindo assim a diferenciação desta estirpe de outras (LIMA et al., 2006). 
Tabela 2 - Resultados obtidos por RT-PCR para as amostras de videiras sintomáticas e assintomáticas, avaliadas para a presença de 12 espécies virais.

\begin{tabular}{|c|c|c|c|c|c|c|c|c|}
\hline \multirow{2}{*}{ Vírus } & \multirow{2}{*}{ Oligonucleotídeos } & \multirow{2}{*}{$\begin{array}{l}\text { Localização } \\
\text { fragmento } \\
\text { amplificado }\end{array}$} & \multirow{2}{*}{$\begin{array}{l}\text { Tamanho } \\
\text { fragmento } \\
\quad(\mathrm{pb})\end{array}$} & \multicolumn{5}{|c|}{-----------------------Amostra---------------------- } \\
\hline & & & & CS1 & $\mathrm{CS} 2$ & IS1 & IS2 & IS3 \\
\hline GVA & 766/C1197 & $\mathrm{CP}$ & 451 & - & - & - & - & - \\
\hline GVB & GVB_v/GVB_c & $\mathrm{CP}$ & 693 & - & - & - & - & - \\
\hline GVD & GVD_v/GVD_c & $\mathrm{CP}$ & 963 & - & - & - & - & - \\
\hline \multirow{2}{*}{ GFkV } & GFkV_v/GFkV_r & $\mathrm{CP}$ & 693 & - & - & - & - & - \\
\hline & GFkV_v/GFkV_c & REP & 245 & - & - & - & - & - \\
\hline GFLV & GFLVs2515/GFLVa3300 & $\mathrm{CP}$ & 809 & - & - & - & - & - \\
\hline ArMV & $\mathrm{H} 428 \mathrm{v} / \mathrm{C} 867 \mathrm{c}$ & $\mathrm{CP}$ & 440 & - & - & - & - & - \\
\hline \multirow{2}{*}{$\mathrm{RSPaV}$} & RSPaV_v1/RSPaV_c1 & $\mathrm{CP}$ & 780 & $(+)^{*}$ & + & + & $(+)^{*}$ & + \\
\hline & RSP2/RSP21 & REP & 831 & - & $(+)^{*}$ & $(+)^{*}$ & - & - \\
\hline RSPaV-PN & 2R/PN1F & MTR & 505 & - & - & - & - & - \\
\hline RSPaV-SY & SY9F/SY8R & REP & 628 & + & + & + & + & $(+)^{*}$ \\
\hline \multirow{2}{*}{ GLRaV-1 } & GLRaV-1_v/GLRaV-1_r & $\mathrm{CP}$ & 969 & - & - & - & - & - \\
\hline & $\mathrm{LRA} / \mathrm{CPdR}$ & $\mathrm{CPd} 2$ & 1019 & - & - & - & - & - \\
\hline GLRaV-2 & $\mathrm{V} 2 \mathrm{CPf} / \mathrm{V} 2 \mathrm{CPr} 2$ & $\mathrm{CPm}$ & 431 & + & $(+)^{*}$ & + & + & $(+)^{*}$ \\
\hline GLRaV-3 & LR3 8504v/LR3 9445c & $\mathrm{CP}$ & 942 & - & - & + & $(+)^{*}$ & + \\
\hline GLRaV-4 & LR4f/LR4r & ORF1 e 2 & 500 & - & - & - & - & - \\
\hline GCMV & GCMVs/GCMVa & $\mathrm{CP}$ & 391 & - & - & - & - & - \\
\hline Closterovirus & HSP-P1/HSP-P2 & HSP70 & $593-623$ & $(+)^{\mathrm{LR} 2}$ & + & $(+)^{\mathrm{LR} 3}$ & + & + \\
\hline Tricho/Vitivirus & dPR1_v/dPR2_c & REP & 339 & - & + & + & $(+)^{\mathrm{RSP}}$ & - \\
\hline Betaflexiviridae & dRW up1/dRW do2 & REP & 339 & + & $(+)^{\mathrm{RSP}}$ & + & + & + \\
\hline
\end{tabular}

$(+)^{*}$ Clones obtidos com oligonucleotídeos específicos e com sequências de nucleotídeos depositadas no GenBank.

$(+)^{\text {LR2, LR3, RSP }}$ Clones obtidos com oligonucleotídeos degenerados, identificados após sequenciamento de nucleotídeos e com sequências depositadas no GenBank.

CS: cv. 'Cabernet Sauvignon' (sintomática); IS: cv. 'Isabel' (assintomática).

CP (gene da proteína capsidial); REP (gene da replicase viral); HSP70 (gene da proteína de choque térmico 70); MTR (metiltransferase); ORF (open reading frame).

Neste estudo, foram sequenciados 12 isolados virais: sete de RSPaV, três de GLRaV-2 e dois de GLRaV-3 (Tabela 2), os quais tiveram suas sequências depositadas no GenBank (Tabela 3). Pela análise de identidade de nt do gene completo da CP (780pb), verifica-se que os isolados de RSPaV CS1 e IS2a apresentaram maiores identidades de nt com as estirpes SG1 $(95,7 \%)$ e BS $(91,5 \%)$, respectivamente. As identidades de nt e aad entre os dois isolados caracterizados foram de $84,7 \%$ e $81,8 \%$, respectivamente. ALABI et al. (2010) analisaram, com base na análise filogenética do gene da proteína capsidial, 84 isolados de RSPaV, incluindo nove isolados brasileiros, caracterizados por RADAELLI et al. (2009), que se agruparam com a estirpe típica "GRSPaV-1" (isolados 420A, MG, CF210, CF208, MH, CF195-2, PN e CF207) e com a estirpe "GRSPaV-BS" (isolado CF195). MENG et al. (2005b) demonstraram experimentalmente que a infecção da videira cv. 'St. George' com a estirpe SG1 é assintomática.

Para aqueles isolados dos quais foi amplificado o gene da replicase incompleto $(831 \mathrm{pb})$ do $\mathrm{RSPaV}$, verificou-se que estes isolados (CS2a e IS1) apresentaram maiores identidades de nt com as estirpes SG1 (92,4\%) e GRSPaV-1 (96,2\%), respectivamente (Tabela 3). A análise de identidade de nt dos isolados, dos quais se amplificou parte do gene da replicase (339pb) de RSPaV, demonstrou que o isolado IS2b apresentou maior identidade de nt com a estirpe SG1 $(91,0 \%)$ e que o isolado CS2b apresentou maior identidade de nt com o isolado Hail (96,1\%), não permitindo a identificação de uma estirpe homóloga (Tabela 3). Para o isolado IS3, do qual foi amplificado parte do gene da replicase $(628 \mathrm{pb})$ do $\mathrm{RSPaV}$, verificaram-se maiores identidades de nt e aad com a estirpe SY (91,1\% e 93,3\%, respectivamente) (Tabela 3), confirmando os resultados obtidos na RT-PCR, com os oligonucleotídeos específicos para esta estirpe viral (Tabela 2).

Pela análise de identidade de nt dos isolados em que foi amplificado o gene da CP incompleto (431pb) do GLRaV-2, verificou-se que os isolados CS2 e IS3 apresentaram maiores identidades de nt e aad com a estirpe H4 (92,5\% (nt) e 93,7\% (aad); 92,7\% (nt) e 93,6\% (aad), respectivamente) (Tabela 3). A identidade de nt entre os dois isolados foi alta $(98,8 \%)$. A estirpe $\mathrm{H} 4$ foi 
Tabela 3 - Porcentagem (\%) de identidade de nucleotídeos entre as estirpes dos vírus RSPaV, GLRaV-2 e GLRaV-3 e os isolados virais desses mesmos vírus, caracterizados neste trabalho.

\begin{tabular}{|c|c|c|c|c|c|c|}
\hline Vírus & $\begin{array}{c}\text { Gene } \\
\text { sequenciado }\end{array}$ & $\begin{array}{l}\text { Tamanho } \\
\text { fragmento } \\
(\mathrm{pb})\end{array}$ & $\begin{array}{c}\text { Isolado } \\
\text { caracterizado }\end{array}$ & $\begin{array}{l}\text { Isolado caracterizado - } \\
\text { código GenBank }\end{array}$ & $\begin{array}{l}\text { Estirpe viral de maior } \\
\text { identidade }\end{array}$ & $\%$ identidade de nt \\
\hline \multirow{7}{*}{$\mathrm{RSPaV}$} & \multirow{2}{*}{$\mathrm{CP}$ (completa) } & \multirow[t]{2}{*}{780} & CS1 & GU166289 & SG1 - EUA & 95,7 \\
\hline & & & IS $2 a$ & GU166290 & BS - Canadá & 91,5 \\
\hline & \multirow{5}{*}{ REP (parcial) } & \multirow[t]{2}{*}{831} & CS2a & HM059036 & SG1 - EUA & 92,4 \\
\hline & & & IS1 & HM059037 & GRSPaV-1- EUA & 96,2 \\
\hline & & 339 & IS $2 b$ & HM358051 & SG1 - EUA & 91,0 \\
\hline & & & $\mathrm{CS} 2 \mathrm{~b}$ & HM059038 & Hai1 - Japão* & 96,1 \\
\hline & & 628 & IS3 & HM130524 & SY - EUA & 91,1 \\
\hline \multirow{3}{*}{ GLRaV-2 } & \multirow{2}{*}{$\mathrm{CP}$ (parcial) } & 431 & $\mathrm{CS} 2$ & HM059035 & H4 - Itália & 92,5 \\
\hline & & & IS3 & HM358050 & H4 - Itália & 92,7 \\
\hline & HSP70 (parcial) & 623 & $\mathrm{CS} 1$ & HM059039 & PV20 - França* & 94,8 \\
\hline \multirow{2}{*}{ GLRaV-3 } & CP (completa) & 942 & IS2 & HM059034 & NY - EUA & 92,3 \\
\hline & HSP70 (parcial) & 593 & IS1 & HM059040 & NY - EUA & 94,1 \\
\hline
\end{tabular}

CP (gene da proteína capsidial), REP (gene da replicase viral), HSP70 (gene da proteína de choque térmico 70); *correspondem a isolado viral.

Códigos de nucleotídeos das estirpes no GenBank: SG1 (AY881626), BS (AY881627), GRSPaV-1 (NC_001948), SY (AY368590), H4 (AY697863), NY (NC_004667) e isolados virais: Hai1 (AB277787), PV20 (EF012721).

caracterizada porABOU GHANEM-SABANADZOVIC et al. (2000) como sendo uma variante biológica do GLRaV-2, distinta de outros isolados transmitidos mecanicamente, devido a diferenças nas reações em hospedeiras herbáceas e diferenças significativas na sequência do gene CP. RADAELLI et al. (2009) caracterizaram seis isolados brasileiros deste vírus e, destes, três (M/C, MH e RI) também se mostraram mais próximos da estirpe H4. Para o isolado CS1, do qual foi amplificado um fragmento do gene da proteína HSP70 (623pb) do GLRaV-2, verificou-se maior identidade de nt como isolado PV20 (94,8\%), caracterizado por BEUVE et al. (2007), e 74-75,2\% de identidade com as estirpes definidas para este vírus (Tabela 3). Assim, não foi possível identificar a estirpe de GLRaV-2 homóloga ao isolado CS1, com base nesta região do genoma (parte do gene HSP70).

Pela análise de nucleotídeos do isolado IS2, do qual foi amplificado o gene completo (942pb) da CP do GLRaV-3, pôde-se verificar que este isolado apresentou $92,3 \%$ de identidade de nt com a estirpe NY (Tabela 3), destancando-se, ainda, as altas identidades de nt verificadas com os isolados GP18 (98,4\%), da África do Sul, e Pet4 (97,7\%), do Brasil (FAJARDO et al., 2007). Já pela análise de nucleotídeos do isolado IS1, do qual foi amplificado um fragmento do gene da proteína HSP70 (593pb) do GLRaV-3, verificou-se que esse isolado apresentou $94,1 \%$ de identidade de nt com a estirpe NY (Tabela 3), destacando-se, ainda, alta identidade de nt com o isolado WC-HSP-2 (98,1\%), da África do Sul.
A frequente infecção viral múltipla em videiras, como verificado neste trabalho, e a impossibilidade (RSPaV e GLRaV-3) ou a dificuldade de transmissão (GLRaV-2) dessas espécies virais para hospedeiras herbáceas impedem ou dificultam bastante a geração de informações sobre as características biológicas (sintomatologia específica, virulência, etc.) desses vírus e suas estirpes. Entretanto, a determinação da variabilidade viral, correlacionando-a com os sintomas exibidos (ou não) pela videira, reveste-se de importância na busca da melhoria do estado sanitário desta cultura, pois agrega informações sobre as espécies e possíveis estirpes virais, o que resulta em maiores sensibilidade e especificidade nos testes diagnósticos.

\section{CONCLUSÃO}

Videiras vinífera sintomática e americana assintomática podem ser portadoras de infecções múltiplas constituídas por diferentes espécies virais, além de apresentarem-se infectadas por estirpes virais. $\mathrm{O}$ conhecimento da variabilidade dessas espécies e estirpes virais permite incremento de qualidade nos testes diagnósticos.

\section{COMITÊ DE ÉTICA E BIOSSEGURANÇA}

O Certificado de Qualidade em Biossegurança (CQB) da Embrapa Uva e Vinho está registrado na Comissão Técnica Nacional de Biossegurança (CTNBio) sob o número 0227/06. 


\section{REFERÊNCIAS}

ABOU GHANEM-SABANADZOVIC, N. et al. Properties of a new isolate of Grapevine leafroll-associated virus 2. Vitis, v.39, p.119-121, 2000. Disponível em: <http://www.vitisvea.de/admin/volltext/e046268.pdf>. Acesso em: 05 out. 2010.

ALABI, J.A. et al. Sequence diversity, population genetics and potential recombination events in Grapevine rupestris stem pitting-associated virus in Pacific North-West vineyards. Journal of General Virology, v.91, p.265-276, 2010.

BASSO, M.F. Desenvolvimento de ferramentas sorológicas e moleculares para identificação de vírus em videiras e cochonilhas, alterações fisiológicas e na qualidade enológica da uva de videiras infectadas. 2010. 114f. Dissertação (Mestrado em Agronomia) - Curso de Pós-graduação em Agronômia, Universidade Estadual de Ponta Grossa, PR.

BERTAZZON, N.; ANGELINI, E. Advances in the detection of Grapevine leafroll-associated virus 2 variants. Journal of Plant Pathology, v. 86, p.283-290, 2004. Disponível em: <http://www.sipav.org/main/jpp/volumes/0404/040402.pdf>. Acesso em: 05 out. 2010

BEUVE, M. et al. A sensitive one-step real-time RT-PCR method for detecting Grapevine leafroll-associated virus 2 variants in grapevine. Journal of Virological Methods, v.141, p.117124, 2007. Disponível em: <http://www.sciencedirect.com/ science? ob=MImg\& imagekey=B6T96-4MV19MY-1 N\&_cdi $=5106 \&$ user $=7430124 \&$ pii $=$ S0 $166093406004204 \&$ origin $=$ browse \& coverDate $=05 \% 2$ F31\%2F2007\&_sk $=9985899$ $97 \& \mathrm{v}$ i e $\mathrm{w}=\mathrm{c} \& \mathrm{w} \mathrm{c} \mathrm{h} \mathrm{p}=\mathrm{d}$ G L b V t b zSkzk\&md5 $=4 c 52$ e0f193704a27a2da3091 dc48bc $1 \mathrm{c} \& i e=/$ sdarticle.pdf $>$. Acesso em: 05 out. 2010. doi:10.1016/ j.jviromet.2006.11.042.

FAJARDO, T.V.M. et al. Caracterização parcial de um isolado do Grapevine fanleaf vírus. Fitopatologia Brasileira, v.25, p.505-511, 2000.

FAJARDO, T.V.M. et al. Doenças virais. In: FAJARDO, T.V.M. Uva para processamento - Fitossanidade. Série Frutas do Brasil 35. Brasília: Embrapa Informação Tecnológica, 2003. p. 45-62.

FAJARDO, T.V.M. et al. Variability of the coat protein gene of Grapevine leafroll-associated virus 3 in Brazil. Fitopatologia Brasileira, v.32, p.335-340, 2007. Disponível em: <http:// www.scielo.br/pdf/fb/v32n4/08.pdf>. Acesso em: 05 out. 2010. doi: 10.1590/S0100-41582007000400008.

GIOVANNINI, E. Produção de uvas para vinho, suco e mesa. 3.ed. Porto Alegre: Renascença, 2008. 368p.

KOVACS, L.G. et al. Latent infection by leafroll agent GLRaV3 is linked to lower fruit quality in French-American hybrid grapevines Vidal blanc and St. Vincent. American Journal of Enology and Viticulture, v.52, p.254-259, 2001.

LIMA, M.F. et al. Molecular analysis of a California strain of Rupestris stem pitting associated virus isolated from declining Syrah grapevines. Archives of Virology, v.151, p.1889-1894, 2006. Disponível em: <http://www.springerlink.com.w10106.dotlib.com.br/ content/9864552221670162/fulltext.pdf $>$. Acesso em: 05 out. 2010. doi: 10.1007/s00705-006-0742-y.
LIMA, M.F. Detecção e controle de viroses em videira. Petrolina: Embrapa Semiárido, 2009. 9p. Disponível em: $<$ http://www.cpatsa.embrapa.br:8080/public_eletronica/ downloads/CTE90.pdf>. Acesso em: 13 ago. 2010.

LIMA, M.F. et al. Genomic study and detection of a new variant of Grapevine rupestris stem pitting associated virus in declining California Pinot Noir grapevines. Journal of Plant Pathology, v.91, p.155-162, 2009. Disponível em: <http:// www.sipav.org/main/jpp/volumes/0109/010917.pdf>. Acesso em: 05 out. 2010.

LING, K.S. et al. The coat protein gene of Grapevine leafroll-associated closterovirus 3: cloning, nucleotide sequencing and expression in transgenic plants. Archives of Virology, v.142, p.1101-1116, 1997. Disponível em: $<$ http://www.springerlink.com.w10106.dotlib.com.br/ content/934gve92efw70c7j/fulltext.pdf $>$. Acesso em: 05 out. 2010 .

MARTELLI, G.P. Grapevine virology highlights 2006-09. In: MEETING OF INTERNATIONAL COUNCIL OF VIRUSES AND VIRUS DISEASES OF GRAPEVINE, 16., 2009, Dijon, France. Extended abstracts... Dijon:ICVG, 2009. p.15-23.

MENG, B. et al. Rupestris stem pitting-associated virus-1 is consistently detected in grapevines that are infected with rupestris stem pitting. European Journal of Plant Pathology, v.105, p.191-199, 1999. Disponível em: <http:/ /www.springerlink.com.w10106.dotlib.com.br/content/ m032206542842388/fulltext.pdf>. Acesso em: 05 out. 2010.

MENG, B. et al. Genome sequences and structures of two biologically distinct strains of Grapevine leafroll-associated virus 2 and sequence analysis. Virus Genes, v.31, p.31-41, $2005 \mathrm{a}$.

MENG, B. et al. Complete genome sequences of two new variants of Grapevine rupestris stem pitting-associated virus and comparative analyses. Journal of General Virology, v.86, p.1555-1560, 2005b. Disponível em: <http://vir.sgmjournals.org/ cgi/reprint/86/5/1555>. Acesso em: 05 out. 2010. doi: 10.1099/ vir. $0.80815-0$.

MENG, B. et al. Genetic diversity analyses of Grapevine rupestris stem pitting-associated virus reveal distinct population structures in scion versus rootstock varieties. Journal of General Virology, v.87, p.1725-1733, 2006. Disponível em: <http://vir.sgmjournals.org/cgi/reprint/87/6/1725>. Acesso em: 05 out. 2010. doi: 10.1099/vir.0.81533-0.

MONIS, J. et al. Avances en el estúdio de enfermedades de la vid provocadas por virus. Revista Enología, AñoVII, p.1-8, 2010.

RADAELLI, P. et al. Variabilidade do gene da proteína capsidial de três espécies virais que infectam videiras no Brasil. Tropical Plant Pathology, v.34, p.297-305, 2009. Disponível em: $<$ http://www.scielo.br/pdf/tpp/v34n5/v34n5a02.pdf >. Acesso em: 04 out. 2010. doi: 10.1590/S1982-56762009000500002.

SAMBROOK, J.; RUSSEL, D. Molecular cloning: a laboratory manual. 3.ed. New York: Cold Spring Harbor Laboratory, 2001. 999p.

VALVERDE, R.A. et al. Analysis of double-stranded RNA for plant virus diagnosis. Plant Disease, v.74, p.255-258, 1990. 